\title{
Digital evaluation of the influence of interruption of the fixation process on radiographic contrast and base-plus-fog density in three commercial brands of radiographic films
}

\author{
Avaliação digital da influência da interrupção da fixação no contraste radiográfico e na densidade base e \\ velamento em três marcas comerciais de filmes radiográficos
}

\author{
Paula Verona Ragusa da SILVA ${ }^{a}$, Renan Roberto da COSTA ${ }^{\mathrm{b}}$, Mariliani Chicarelli da SILVAc, \\ Lilian Cristina Vessoni IWAKI ${ }^{c}$, Wilton Mitsunari TAKESHITA ${ }^{\mathrm{d}}$ \\ ${ }^{a}$ ACCCC - AC Camargo Cancer Center, São Paulo, SP, Brasil \\ ${ }^{b}$ Faculdade de Odontologia, UNESP - Univ Estadual Paulista, Araraquara, SP, Brasil \\ 'UEM - Universidade Estadual de Maringá, Maringá, PR, Brasil \\ ${ }^{d}$ UFS - Universidade Federal de Sergipe, Aracaju, SE, Brasil
}

\begin{abstract}
Resumo
Introdução: Com a preocupação em antecipar o acesso ao resultado de radiografias intrabucais, o processamento radiográfico é muitas vezes negligenciado, comprometendo a qualidade da imagem. Objetivo: $\mathrm{O}$ objetivo deste trabalho foi avaliar a influência da interrupção do processo de fixação no contraste radiográfico e na densidade base e velamento (DBV) em 3 marcas comerciais de filmes periapicais. Material e método: Foram realizadas 90 radiografias de um stepwedge de alumínio e uma placa de chumbo para cada marca, e as mesmas foram divididas de acordo com o tempo de imersão inicial no fixador em: grupo controle (sem interrupção na fixação), 5, 10, 20, 30 e 40 segundos. Durante o processamento, os filmes tiveram a fixação interrompida e foram expostos à luz de um negatoscópio por 1 minuto, e então completaram o tempo de fixação de 10 minutos. As radiografias foram digitalizadas e analisadas no software Image Tool 3.0. Resultado: O filme Kodak ${ }^{\circledR}$ não apresentou diferenças estatísticas significantes entre os grupos, enquanto que o filme Agfa ${ }^{\circledR}$ apresentou diferença na DBV em relação ao grupo de 5 segundos, e o filme Dentix ${ }^{\circledR}$ apresentou diferença estatística em todos os grupos comparando-os ao grupo controle. Conclusão: Sob as condições estudadas, o filme Kodak ${ }^{\circledR}$ não sofreu influência da interrupção da fixação na DBV e no contraste da imagem, possibilitando o acesso antecipado ao resultado do exame radiográfico, enquanto que o filme Agfa ${ }^{\circledR}$ necessita de pelo menos 10 segundos de fixação inicial e o filme Dentix ${ }^{\circledR}$ obtém melhores resultados quando não interrompido o processo de fixação.
\end{abstract}

Descritores: Intensificação de imagem radiográfica; radiografia dentária; filme para raios X.

\begin{abstract}
Introduction: With the interest in anticipating access to the result of intraoral radiography, the radiographic processing is frequently neglected, compromising image quality. Objective: The aim of this study was to evaluate the influence of interrupting the fixation process on the radiographic contrast and base-plus-fog density (BPFD) in three brands of periapical films. Material and method: Ninety radiographs were taken of an aluminum stepwedge and a lead plate for each brand, and they were divided according to the time of initial immersion in the fixative in: control group (without interrupting the fixing), 5, 10, 20, 30 and 40 seconds. During processing, films had the fixing stage stopped and were exposed to a negatoscope for 1 minute, then the fixation time of 10 minutes was completed. The radiographs were digitized and exported to Image Tool 3.0.software. Result: Kodak ${ }^{\circledR}$ film showed no statistically significant differences between groups, while Agfa ${ }^{\circledR}$ film presented difference in BPFD compared with Group 5 seconds, and Dentix ${ }^{\circledR}$ film showed statistical difference in all groups in comparison with the control group. Conclusion: Under the conditions studied, Kodak ${ }^{\circledR}$ film is not influenced by disruption of fixation as regards BPFD and image contrast, enabling early access to the results of radiographs, whereas Agfa ${ }^{\circledR}$ film requires at least 10 seconds of initial fixation, and Dentix ${ }^{\circledR}$ film obtains better results when the process of fixation is not interrupted.
\end{abstract}

Descriptors: Radiographic image enhancement; radiography, dental; x-ray film. 


\section{INTRODUCTION}

A good quality radiographic exam is fundamental for correct diagnosis in various situations in clinical dentistry ${ }^{1}$. It allows detection of the presence of pathologies, anomalies, in addition to confirmation of the integrity of dental structures ${ }^{2,3}$. For adequate radiographic interpretation, strict quality control of image capture is fundamental ${ }^{4}$. This consists of continued evaluation of the energy factors related to exposure to X-rays, image processing, patient protection and gain of working time. Command of all the stages of the radiographic exam and a careful technique may diminish the time of attending patients, as these factors prevent unnecessary repetitions ${ }^{5}$.

Therefore, adequate contrast and base-plus-fog density (BPFD) are fundamental criteria for correct interpretation of the images obtained, since radiographic contrast is translated by the graduation of the different densities of films in different areas of a radiograph ${ }^{1^{*}}$; and BPFD represents the optical density inherent to the radiographic film ${ }^{6}$, which may result from the quality of the emulsion and its interaction with the processing solutions, secondary radiation, and safety light ${ }^{5 * *}$.

Continuing studies must be conducted to evaluate different brands of films with regard to their respective BPFDs, with a view to quality control in dental radiography ${ }^{6,7}$, bearing in mind that with technological advancement, new commercial brands of films are introduced into the market.

Moreover, it has been noted that many professionals neglect the radiographic processing procedure in daily practice, particularly the stage of fixation, although they are aware that in order to obtain a quality image, it is important for all the stages of the radiographic exam to be performed correctly, starting with film storage and through to its final drying. This is mainly due to the need for reducing the working time and the apparent ease of performing the technique.

As a result of this, and concern about anticipating access to intraoral radiographic results, without compromising their quality, the aim of this study was to make a digital evaluation of the influence of interrupting the fixation process on radiographic contrast and base-plus-fog density (BPFD) of 3 commercial brands of periapical films.

\section{MATERIAL AND METHOD}

For this research a stepwedge (aluminum equivalence scale $)^{8,9}$, made of a specific and internationally standardized alloy (aluminum alloy 2026, ABNT), consisting of eight steps measuring $1 \mathrm{~mm}$ in height each, in addition to a lead plate with an area of $1 \mathrm{~cm}^{2}, 30 \mathrm{Kodak}^{\circledR}$ Insight periapical films, sensitivity F (Eastman Kodak Company, Rochester, USA), 30 films Agfa ${ }^{\circledR}$ Dentus M2 Comfort periapical films, sensitivity E (Agfa-Gevaert,

* Goaz PW, White SC. Processing X-ray film. In: Goaz PW, White SC. Oral radiology, principles and interpretation. St. Louis: Mosby-Year Book; 2009.

** Dezotti MSG. Avaliação de filmes radiográficos periapicais em diferentes condições de processamento pelos métodos sensitométrico, digital e morfométrico [tese doutorado]. Bauru: Faculdade de Odontologia da USP; 2003.
Mortsei, Belgium) and 30 Dentix $^{\circledR}$ periapical films, sensitivity E (Foma Bohemiaspol. s R.O, HradecKrálové, Czech Republic) (Figure 1), totaling 90 radiographic films for the study.

The films were exposed to radiation under standardized technical conditions, on the same day and by the same operator, using the DabiAtlante ${ }^{\circledR}$ (Model Spectro 70x electronic) intraoral radiographic appliance, with mechanical calibration previously verified, and with the technical factors of exposure fixed at $70 \mathrm{kVp}$ and $8 \mathrm{~mA}$, for the time of 0.4 seconds determined by a previous pilot test, containing a lead plate and a stepwedge. The main X-ray beam fell perpendicularly on the film/stepwedge/lead plate, at a distance of $40 \mathrm{~cm}$ (Figure 2).

In the act of processing, a random subdivision was performed for each commercial brand of films, to group them according to the times of initial immersion in the fixer, with the following groups being obtained: Control (without interrupting fixation), 05, 10, 20, 30 and 40 seconds.

Each film was individually processed by one and the same examiner, by the temperature-time method, in a portable $\mathrm{VH}^{\circledR}$ dark chamber (Essence Dental, Araraquara, Brazil), using the ready-to-use $\operatorname{Kodak}^{\circledR}$ (Eastman Kodak Company, Rochester, USA) solutions that were at a temperature of $22^{\circ} \mathrm{C}$. According to the tables provided by the film manufacturers, the immersion time in the developer was 4 minutes, intermediate washing for 20 seconds, complete fixation time of 10 minutes, in addition to final washing for another 20 minutes. To control the method, a thermometer for liquids and a stopwatch were used. So that the deterioration of the solutions due to the quantity of films

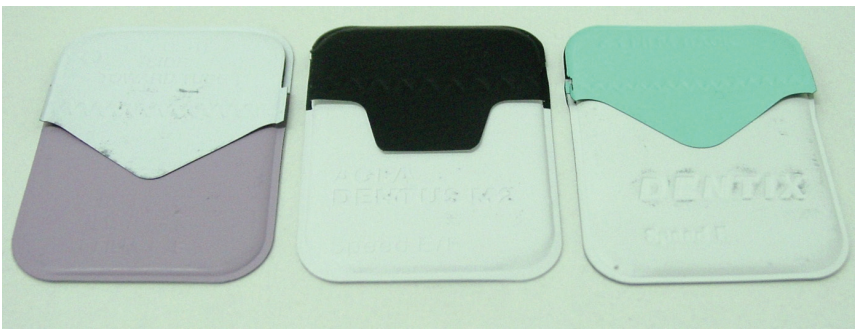

Figure 1. Radiographic Films of three different brands.

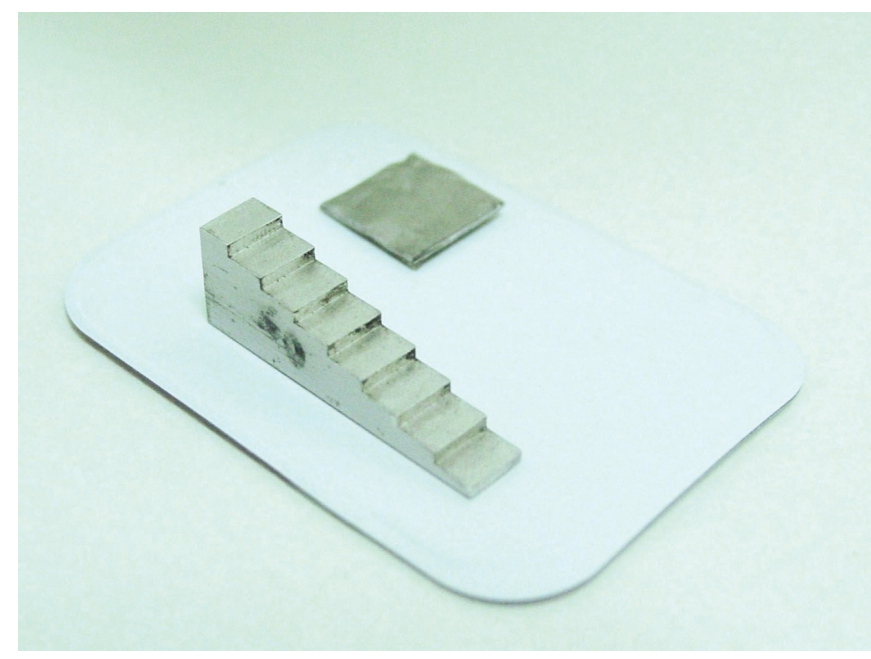

Figure 2. Image of the stepwedge, lead plate and radiographic film, positioned for the radiographic exam. 
processed and oxidation would not interfere in the processing quality of the following radiographs, the processing liquids were changed for each commercial brand.

In accordance with the previously described standards, the radiographs were processed individually. The films of the experimental groups were immersed in the fixer, and when the initial immersion time was up, the stop-watch was stopped, the films were removed from the fixer solution, and then exposed to the light of a negatoscope without coming into direct contact with it, for a period of 60 seconds. Without returning to the receptacle with water, fixation of the films was resumed until the time of 10 minutes was up, then they were immersed in water for 20 minutes. After complete drying, the radiographs were digitized in a scanner with a transparency reader, of the $\mathrm{HP}^{\circledR}$ Scanjet G4050 brand, with an optical digitization resolution of up to 4800 d.p.i. (dots per inch). All the images were captured with a fixed resolution of 300 d.p.i., saved in TIFF (Tagged Image File Format) format and sent to the Image Tool 3.0 software program for analysis of the image of the first and last step of the stepwedge, for the purpose of calculating the contrast and measuring the DPFD.

It is important to point out that for the measurement of the contrast and base-plus-fog density, a scale that ranges from 0 to 255 is used, with 0 being equivalent to black and 255 to white. The intermediate numbers represent the various gray tones present in the image, with the high-density values corresponding to lighter images, and the lower values to darker images ${ }^{7}$.

The data were inserted in the Excel 2010 and SPSS 11.0 software programs, and submitted to the analysis of variance (ANOVA) and Tukey statistical tests, at a $5 \%$ level of significance.

\section{RESULT}

For presentation of the data, two graphs were constructed of mean BPFD and contrast values, in which equal letters correspond to no statistically significant difference at a level of $5 \%$ between the studied means, with the purpose of evaluating the homogeneity between the groups.

When the contrast in the different radiographic films was analyzed, the $\mathrm{Kodak}^{\circledR}$ and $\mathrm{Agfa}^{\circledR}$ brands presented no statistically significant differences between the different groups with interruption of fixation. However, the films in the experimental groups of the Dentix ${ }^{\circledR}$ brand presented considerable difference in comparison with the control group, with this difference being more significant in the group of interruption for 5 seconds (Figure 3).

When analyzing the BPFD, constant values were observed for $\operatorname{Kodak}^{\circledR}$ film. The $\mathrm{Agfa}^{\circledR}$ brand presented values close to those of the Kodak ${ }^{\circledR}$ brand, however, in the group in which there was an interruption of 5 seconds, a difference was observed in comparison with the control group and other groups. When the results with reference to the Dentix ${ }^{\circledR}$ film were analyzed, it was observed that all the groups presented differences in comparison with the control, with these being more significant in the groups with interruptions of 5 and 10 seconds (Figure 4).

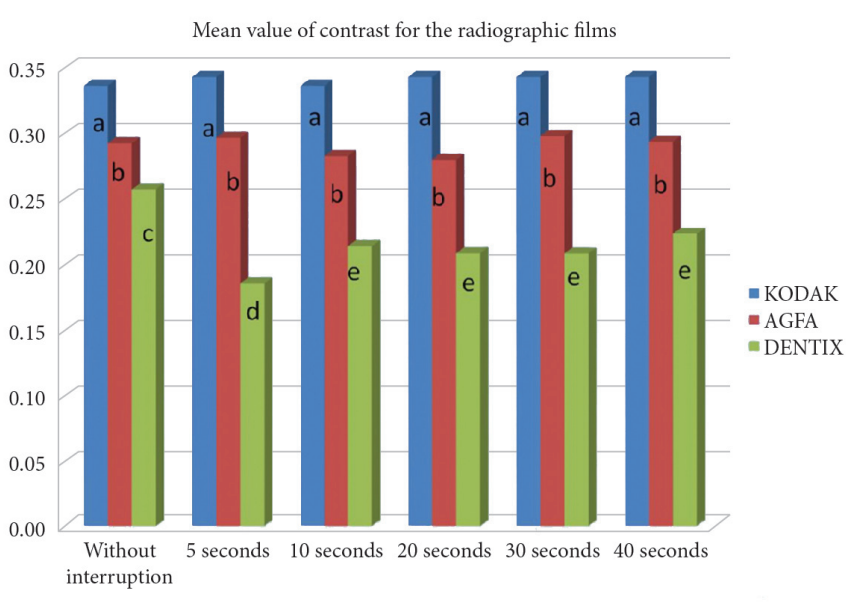

Figure 3. Mean value of contrast for the different radiographic films. Equal letters correspond to no statistically significant difference at the level of $5 \%$.

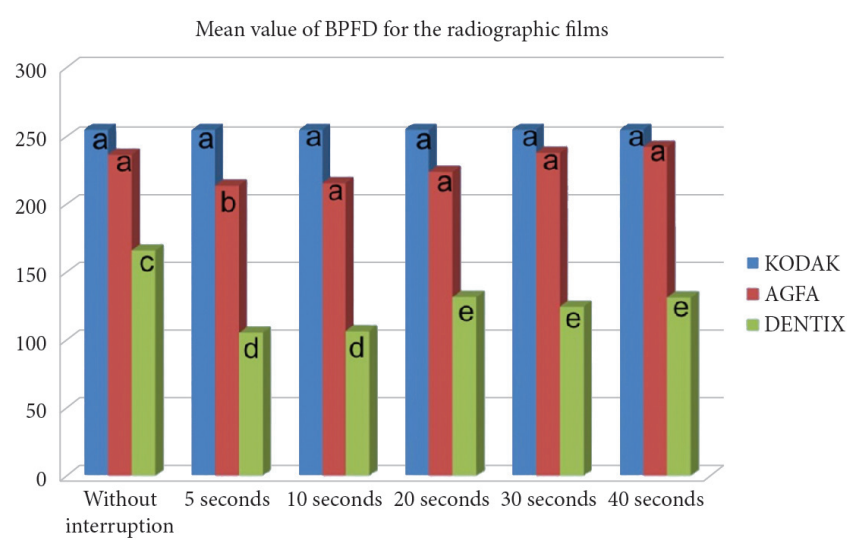

Figure 4. Mean value of BPFD for the different radiographic films. Equal letters correspond to no statistically significant difference at the level of $5 \%$.

\section{DISCUSSION}

Daily dental practice demands the use of radiographs with speed, with a view to reducing the time of work. Both in specialized procedures and those in the general clinical, the professional encounters situations in which there is a need for obtaining good quality radiographs quickly. However, interrupting the fixation of the radiograph, frequently done by clinicians for this purpose, results in the loss of details in the radiographic image. Over time, the poorly fixed radiographs present a yellowed color and the image formed tends to disappear, by virtue of the absence of an effective protective barrier ${ }^{8}$.

Moreover, the use of good quality radiographs is imperative for making a correct diagnosis and treatment in the various situations of the dental clinic, and particularly for documentation $^{3,9}$. Therefore, the dentist must use means that optimize processing, but continue to guarantee a satisfactory result. Knowing the importance of the use of radiographs as an auxiliary diagnostic method, there is the challenge of reducing the risk offered by radiation doses, avoiding unnecessary repetitions, and diminishing the clinical working time ${ }^{5}$, and nevertheless 
continue to obtain radiographs rich in details by means of a well performed technique.

In seeking better results and greater speed, some authors have suggested the use of careful automatic processors with respect to all the stages and conditions of processing ${ }^{2}$. However, in Brazil, the low flow of patients or high cost of acquiring an automatic processor make it unfeasible for all the private dental offices or those of the national health system to purchase such a unit. Therefore, all that remains is to carefully comply with all the steps involved in obtaining a high quality radiograph, and this is classified as such when it presents the maximum amount of details, medium contrast and density and minimal distortion ${ }^{3}$.

These criteria may be influenced by various factors, among them the choice of radiographic film used and the radiographic processing technique. Although radiographic processing is considered an easy-to-perform procedure, it is responsible for a large portion of imaging errors ${ }^{10,11}$. There continues to be controversy about the ideal time of immersion of the radiographic film in the fixation liquid ${ }^{3}$, however, it is recommended that the time demanded by the radiographic film manufacturer should be respected, which suggests a mean of 2 to 4 minutes, while the literature recommends the time corresponding to double the amount of time necessary for the milky image to become transparent, which occurs in around 8 to 10 minutes ${ }^{3}$.

The quality of radiographs largely depends on their correct manipulation in accordance with the film manufacturer's instructions. Casanova et al. ${ }^{9}$ and Lourenço et al. ${ }^{3}$ have made reference to various factors, such as the type of film, types of solutions, forms of processing, development temperature, final washing, drying, sensitivity, contrast and BPFD, as factors potentially responsible for the poor quality of radiographs.

Among the means of processing most commonly used by dentists, the manual inspection method has been observed to be the most frequently used. However, some researches have shown that under-processing occurs in a large portion of dental offices ${ }^{10-14}$, which may undoubtedly induce diagnostic errors. Lemke et al. ${ }^{15}$, in their research, verified that the majority of professionals evaluated were performing radiographic overexposure, in order to under-process the radiographs afterwards, with the aim of reducing working time.

In seeking image quality we may use the BPFD as a means of measurement. The BPFD is the specific density of the film itself, and may be influenced by the processing solutions, secondary radiation and safety light, which interact with this film. Costa et al. ${ }^{6}$ mentioned that studies analyzing BPFD of the different radiographic films should be continually conducted in order to obtain quality control of dental radiographs.

According to Lourenço et al. ${ }^{3}$, literature on the subject is scarce, however, as has been mentioned, it is fundamental to maintain radiographic quality within the dental office. In view of the foregoing, the present study sought to evaluate the BPFD of three commercial brands (Kodak ${ }^{\circledR}$, Agfa $^{\circledR}$ and Dentix ${ }^{\circledR}$ ), as well as the contrast of films by means of using a digital software program that enabled richer details to be obtained. The $\operatorname{Kodak}^{\circledR}$ and Agfa ${ }^{\circledR}$ brands were chosen because they have been on the market for many years, and Dentix ${ }^{\circledR}$ because it is a relatively new brand in Brazilian industry.
In the present research, no statistically significant differences were observed as regards BPFD and contrast in the group of $\operatorname{Kodak}^{\circledR}$ films, however, there was evidence of some variations when analyzing films of the Agfa ${ }^{\circledR}$ and Dentix ${ }^{\circledR}$ brands, with these results being in agreement with the above-mentioned literature. However, it is pointed out that films with different sensitivities were used (Kodak ${ }^{\circledR}$ sensitivity F, Agfa ${ }^{\circledR}$ sensitivity E and Dentix ${ }^{\circledR}$ sensitivity E), due to the restricted availability on the market, and we do not discard the hypothesis that this fact may have contributed to the different performance of the radiographic brands with reference to contrast and BPFD.

Some studies have investigated the interruption of fixation of the radiograph by the automated ${ }^{16,17}$ and manual method of processing, and when they used the automated method with Kodak $^{\circledR}$ films, they observed acceptable BPFD values for all the types of films. Araujo et al. ${ }^{2}$ (2009), when interrupting manual processing, did not observe interference in BPFD and contrast of the radiographic image, provided that the films were returned to the solution for complete fixation. However, the study of Kaugars et al. ${ }^{18}$, analyzing different types of films, showed evidence of a trend towards increase in BPFD as a result of type of film and processing condition.

Lourenço et $\mathrm{al}^{3}{ }^{3}$, in their study, observed that the interruption of fixation followed by reading in the negatoscope did not interfere in the base-plus-fog density and contrast of the radiographic image, even after a period of six months of filing the films, a fact that differs from the finding of the research here presented. According to this same author, the results found by them suggest the involvement of two factors: the fixing solution remaining on the film during the period of reading in the negatoscope, which allows continuation of the action of sodium hypochlorite in removal of the silver grains, and the return to the fixer for conclusion of fixation after the time the film stayed in the negatoscope. Even if this hypothesis is sound, in the present study these suppositions could not be confirmed, bearing in mind the discrepancy in the result found for the Dentix ${ }^{\circledR}$ film.

Although there are recommendations from the manufacturers that fixation should be performed in an uninterrupted manner, in this search it was found that suspension of fixation for a few seconds could be indicated for the films from the manufacturers $\operatorname{Kodak}^{\circledR}$ and $\mathrm{Agfa}^{\circledR}$, provided that for the latter, a minimum time of 10 seconds of initial fixation is respected, and that both return to the fixer to complete the pre-determined time of 10 minutes. On the other hand, the results of this study point out that the processing of the Dentix ${ }^{\circledR}$ films must be carried out faithfully in accordance with the manufacturer's instructions.

\section{CONCLUSION}

According to the conditions studied, it could be concluded that:

- For Kodak ${ }^{\circledR}$ film there was no influence of the interruption of fixation on BPFD and contrast of the image, making it possible to anticipate access to the result of the radiographic exam;

- Agfa ${ }^{\circledR}$ film needs a minimum time of 10 seconds of initial fixation in order to have no interference in the BPFD;

- Dentix ${ }^{\circledR}$ film obtained satisfactory results only when the fixation process was not interrupted. 


\section{REFERENCES}

1. Changizi V, Jazayeri E, Talaeepour A. Study of densitometry comparison among three radiographic processing solutions. Iran J Radiat Res. 2006;4(2):81-6.

2. Araujo AMM, Pontual AA, Silveira MMF, Brasileiro IV, Pontual MLA. Influência da interrupção da fixação no contraste radiográfico e na densidade base e velamento. Rev Assoc Paul Cir Dent. 2009;63(5):409-14.

3. Lourenço ADA, Pontual AA, Silveira MMF, Pontua, MLA. Radiographic image quality after interruption of the fixing stage to view the image with a viewbox. Rev Odonto Ciênc. 2010;25(1):78-82. http://dx.doi.org/10.1590/S1980-65232010000100016

4. Thornley PH, Stewardson DA, Rout PGJ, Burke FJT. Assessing the quality of radiographic processing in general dental practice. Br Dent J. 2006;200:515-9. http://dx.doi.org/10.1038/sj.bdj.4813527

5. Brücker MR, Tavano O, Costa NP. Análise do comportamento das soluções RPX-Omat da Kodak através do método sensitométrico. Rev Odonto Ciênc. 1992;7(13):37-52.

6. Costa C, David AF, David SMN, Matsui RH, Castilho JCM, Varoli FP. Estudo das densidades base e velamento obtidas de filmes radiográficos em diferentes condições de processamento. Ciênc Odontol Bras. 2005;8(1):90-6.

7. Travessas JAC, Mahl CRW, Fontanella, VRC. Avaliação da densidade radiográfica digital de quatro filmes periapicais. Rev Fac Odontol Porto Alegre. 2004;45(2):17-20.

8. White SC, Pharoah MJ. Radiologia oral: princípios e interpretação. St Louis: Mosby; 2007.

9. Casanova MA, Haiter-Neto F, Bóscolo FN, Almeida SM. Sensitometric comparisons of insight and Ektaspeed Plus Films: effects of chemical developer depletion. Braz Dent J. 2006;17(2):149-54. http://dx.doi.org/10.1590/S0103-64402006000200013

10. Pontual ML, Veloso HHP, Pontual AA, Silveira MMF. Errores en radiografias intrabucales realizadas en la Facultad de Odontología de Pernambuco-Brasil. Acta Odontol Venez. 2005;43:19-24.

11. Gasparini D, Vaz EMS, Haiter Neto F, Boscolo FN. Análise de erros radiográficos cometidos por alunos da Faculdade de Odontologia de Piracicaba, no período de 1975 a 1988. Rev Odontol Univ São Paulo. 1992;6:107-14.

12. Sur J, Endo A, Matsuda Y, Itoh K, Katoh T, Araki K, et al. A measure for quantify the radiopacity of restorative resins. Oral Radiol. 2011;27:2227. http://dx.doi.org/10.1007/s11282-010-0055-4

13. De Paula MV, Fenyo-Pereira M. Controle de qualidade em radiografias periapicais - padrões de exposição e revelação. Rev Assoc Paul Cir Dent. 2001;55:355-60.

14. Beltrame M, Oliveira AE, Spyrides KS, Cordeiro PV. Análise do processamento radiográfico nos consultórios de Feira de Santana - BA. Rev Fac Odontol Univ Passo Fundo. 2003;8:50-4.

15. Lemke F, Tavano O, Mezadri AC. Verificação das condições de exposição e processamento de filmes radiográficos em consultórios odontológicos. RPG: Rev Pós-Grad. 2006 abr-jun;13(2):175-80.

16. Costa C, Yamamoto CM, Barbosa J, Saraceni CHC, Armonia PL. Avaliação das densidades óticas de filmes radiográficos digitalizados quando processados pelo método roller. Rev Inst Ciênc Saúde. 2007;25(4):399-402.

17. Geist JR, Brand JW, Pink FE. The effect of automated nonroller processing on the sensitometric characteristics of 3 intraoral film types. Oral Surg Oral Med Oral Pathol Oral Radiol Endod. 2003;96(1):102-11. http://dx.doi.org/10.1016/S1079-2104(03)00221-X

18. Kaugars GE, Broga DW, Collett WK. Dental radiologic survey of Virginia and Florida. Oral Surg Oral Med Oral Pathol. 1995;60(2):225229. http://dx.doi.org/10.1016/0030-4220(85)90300-7

\section{CONFLICTS OF INTERESTS}

The authors declare no conflicts of interest.

\section{CORRESPONDING AUTHOR}

Paula Verona Ragusa da Silva

Rua Professor Antônio Prudente, 211, Liberdade, 01509-900 São Paulo - SP, Brasil

e-mail: paula.ragusa@hotmail.com

Received: September 1, 2013

Accepted: December 10, 2013 